\title{
Mastoid Region Swelling, A Dermoid Cyst: Unusual Presentation
}

Bhushan kathuria* and Himani Dhingra

Consultant ENT Head \& Neck Oncosurgeon, University of Health Sciences, Kainos Hospital Rohtak, India

Submission: December 03, 2019; Published: December 10, 2019

*Corresponding author: Bhushan kathuria, Consultant ENT Head \& Neck Oncosurgeon, University of Health Sciences, Kainos Hospital Rohtak, India

\section{Letter to Editor}

Dermoid cysts of the head and neck are the rare presentation (7\%), mainly encountered in the area of the lateral eyebrow, the orbit and the nose (>80\%) [1]. But dermoid cyst a benign tumor in the subcutaneous tissue of the mastoid region is extremely rare presentation that need further literature attention as still, only single case had been reported in literature [2].

The authors present the case of a 30-year-old female presented with a swelling that had grown gradually under the skin of the left mastoid for 6 months without any pain, hearing loss or vertigo. On examination, $3 \times 2 \mathrm{~cm}$ painless, firm subcutaneous swelling with regular surface was present over left mastoid region. The swelling was soft, cystic and non-tender without any restricted mobility. Skin over the swelling was normal and free. There was no discharging sinus or pointing abscess without any bony indentation. Bilateral ear, external auditory canal and ear drum were normal. There were no facial or cervical deformities. Fine needle aspiration of the swelling was unsatisfactory.

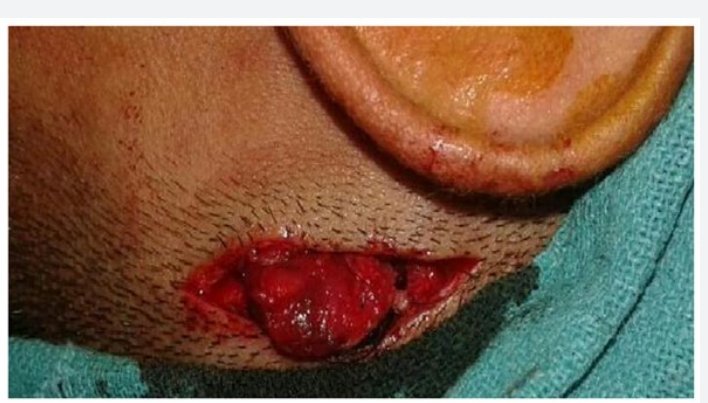

Figure 1: Show swelling in the mastoid region in subcutaneous plane after raising the skin flap.

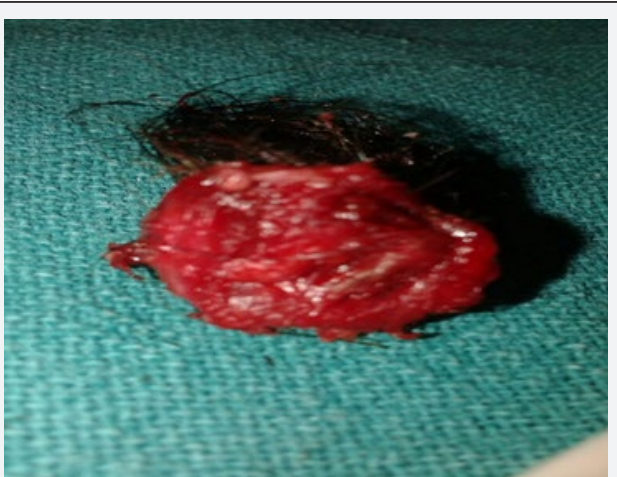

Figure 2: Show bunch of hairs after slivered the specimen.

Clinical diagnosis of a sebaceous cyst of retro auricular region was made and planned for surgical excision. Excision biopsy of the swelling was performed under local anesthesia. An encapsulated cystic mass of size approximating $3 \times 2 \mathrm{~cm}$ with granular surface 
was observed occupying the left mastoid surface beneath skin flap (Figure 1). After slivered the specimen, a bunch of hairs were seen occupying the cavity of the cyst, revealed the diagnosis of dermoid cyst (Figure 2). Histopathological examination of the specimen confirmed the intra-operative finding. Patient is doing well on follow up of 16 months without any recurrence. Although this case was presented with asymptomatic retro-auricular swelling and was easy to manage surgically but it is unwise and unadvisable to do directly surgical intervention of such lump, as dermoid of mastoid, middle ear with or without intra-Dural extension has been reported in the literature $[3,4]$. If the patient present with such unusual swelling, unlikely differential should be kept in mind and further evaluation with imaging is to be done.

\section{References}

1. Batsakis JG (1979) Tumors of the Head and Neck. $2^{\text {nd }}$ edition, Teratomas of the head and neck: Lippincott Williams and Wilkins 226-32.

2. Zhao D, Han Y, Chen Y, Qiu J (2013) An unusual dermoid cyst in subcutaneous tissue of the mastoid region: A case report. Exp Ther Med 6(1): 75-6.

3. Toynbee J (1866) Hairs in the mastoid cells. Transactions of the Pathological Society of London 17: 274.

4. Farris PE, Meyerhoff WL, Vuitch F (1998) Congenital dermoid cyst of the middle ear. Skull Base Surg 8: 77-80.

\section{Your next submission with Juniper Publishers will reach you the below assets}

- Quality Editorial service

- Swift Peer Review

- Reprints availability

- E-prints Service

- Manuscript Podcast for convenient understanding

- Global attainment for your research

- Manuscript accessibility in different formats ( Pdf, E-pub, Full Text, Audio)

- Unceasing customer service

Track the below URL for one-step submission https://juniperpublishers.com/online-submission.php 